\title{
Correction to: Eplet mismatch analysis and allograft outcome across racially diverse groups in a pediatric transplant cohort: a single-center analysis
}

\author{
Mary Carmelle Philogene ${ }^{1,2}$ (1) $\cdot$ Anita Amin $^{3} \cdot$ Sheng Zhou ${ }^{4,5} \cdot$ Olga Charnaya $^{6} \cdot$ Renato Vega $^{1} \cdot$ Niraj Desai $^{4}$. \\ Alicia M. Neu ${ }^{6} \cdot$ Cozumel S. Pruette $^{6}$
}

Published online: 11 December 2019

(C) The Author(s) 2019

\section{Correction to: Pediatric Nephrology https://doi.org/10.1007/s00467-019-04344-1}

The original version of this article unfortunately contained a mistake. In the third paragraph of "Discussion," two references were missing. The correct wording is "Since several studies have documented that a higher eplet mismatch load between donor and recipient is associated with poor transplant outcomes [50,54], it is important to understand the reason for the observed outcomes in the DRT group compared with the SRT group."

In addition, reference [54] is missing in the original. Please find the two cited references below.

The online version of the original article can be found at https://doi.org/ 10.1007/s00467-019-04344-1

Mary Carmelle Philogene

mphilogene@jhmi.edu

1 Department of Medicine, Johns Hopkins School of Medicine, 2041 E. Monument Street, Baltimore, MD 21205, USA

2 Immunogenetics Laboratory, 2041 E. Monument Street, Baltimore, MD 21205, USA

3 Department of Neurology, University of North Carolina School of Medicine, 115 Mason Farm Road, Chapel Hill, NC 27599, USA

4 Department of Surgery, Johns Hopkins University School of Medicine, 720 Rutland Ave Turner 34, Baltimore, MD 21205, USA

5 Department of Epidemiology, Johns Hopkins School of Public Health, Baltimore, MD, USA

6 Department of Pediatric Nephrology, Rubenstein Child Health Building, Johns Hopkins University School of Medicine, $200 \mathrm{~N}$. Wolfe Street, Baltimore, MD 21287, USA
Open Access This article is licensed under a Creative Commons Attribution 4.0 International License, which permits use, sharing, adaptation, distribution and reproduction in any medium or format, as long as you give appropriate credit to the original author(s) and the source, provide a link to the Creative Commons licence, and indicate if changes were made. The images or other third party material in this article are included in the article's Creative Commons licence, unless indicated otherwise in a credit line to the material. If material is not included in the article's Creative Commons licence and your intended use is not permitted by statutory regulation or exceeds the permitted use, you will need to obtain permission directly from the copyright holder. To view a copy of this licence, visit http://creativecommons.org/licenses/by/4.0/.

\section{References}

50. Sullivan PM, Warner P, Kemna MS, Albers EL, Law SP, Weiss NS et al (2015) HLA molecular epitope mismatching and long-term graft loss in pediatric heart transplant recipients. J Heart Lung Transplant 34(7):950-957

54. Wiebe C, Kosmoliaptsis V, Pochinco D et al HLA-DR/DQ molecular mismatch: A prognostic biomarker for primary alloimmunity. Am J Transplant 19(6):1708-1719

Publisher's note Springer Nature remains neutral with regard to jurisdictional claims in published maps and institutional affiliations. 